\title{
Contracting the Right to Roam
}

Wallace McNeish and Steve Olivier

(C) 2017, Palgrave Macmillan, reproduced with permission of Palgrave Macmillan

This extract is taken from the author's original manuscript and has not been edited. The definitive, published, version of record is available in the Palgrave Handbook of Leisure Theory, edited by K. Spracklen et al., available from: http://www.palgrave.com/gp/book/9781137564788 


\title{
Contracting the Right to Roam
}

\author{
Wallace McNeish and Steve Olivier
}

\section{Introduction}

This chapter critically examines the issue of free recreational access to the environment - the right to roam, from the perspective of political philosophy. We begin by setting the right to roam within a comparative socio-legal context that indicates how ongoing social and economic change has moved it to centre stage in the increasingly contested sphere of what Rojek $(2001 ; 2010)$ calls leisure politics. We then move on to consider the politicalphilosophical debate that has traditionally revolved around rights and duties pertaining to private property, and the conception of the social contract. In recent decades the emergence of environmental ethics - and in particular conceptions of environmental sustainability and environmental justice, have added extra dimensions of complexity to the philosophical terrain upon which the right to roam is contested.

Two very different versions of the social contract will be juxtaposed to bring the key arguments into high relief. On the one hand we consider Hardin's influential eco-Hobbesian Tragedy of the Commons (2000, [1968]) thesis. This positions human beings as possessive, selfish and competitive individuals who will inevitably be responsible for generalized environmental degradation, unless their restless desires (including to roam) are held in check by a coercive Green Leviathan. On the other hand, we consider Rawls' A Theory of Justice (1971), which constructs social contract theory from a Kantian premise. This holds that human beings have the capacity to work cooperatively and reciprocally to reach a publically reasoned consensus about the principles of justice through which to allocate rights and duties 
- including the environmental rights and duties that are integral to the right to roam. In other words, for Rawls, human beings have the collective capacity to devise just and fair social arrangements that involve a minimum of coercion - indeed this collective reasoning process is integral to Rawlsian procedure.

We will argue that Hardin's pessimistic, exclusionary and potentially authoritarian conclusions are incompatible with the background consensus concerning the allocation of rights and duties in liberal democratic societies. Hardin should therefore be rejected in favour of an interpretative development of Rawls which views the right to roam as a primary social good that is compatible with a conception of justice as sustainable fairness. This ideal can be used to inform a fair social contract as the basis of an inclusive environmentally sensitive leisure citizenship. Here, the Scandinavian model of allemannsretten points to a progressive way forward for meaningful reform.

\section{Life Politics and Allemannsretten}

Changing patterns of employment, welfare and consumption across the global economy have meant that leisure and recreation are playing an increasingly important role in identity formation, and a key role in the attainment of personal satisfaction, happiness, spiritual fulfilment, well-being and health (see e.g., Gammon and Elkington eds., 2015). Sociologists have long identified the development of global trends towards expressive or post-materialist values (Inglehart, 1990; 2008), whereby self-actualization is sought through life-political activities centred upon personal ethical strategies and lifestyle choices (Giddens, 1989; 1991). In terms of leisure these are often connected with green spaces and the rural environment, where perhaps there remains an element of unpredictability, excitement and a sense of 
authentic connection to the natural world, which stands in contrast to the controlled, bland and sanitized urban world of daily routines of work and home. As Wilson (2000) says:

Given the means and sufficient leisure, a large proportion of the populace backpacks, hunts, fishes, birdwatches, and gardens... they crowd the national parks to view natural landscapes, looking from the tops of prominences out across rugged terrain for a glimpse of tumbling water and animals living free. They travel long distances to stroll along the seashore, for reasons they can't put into words.

Recreation and leisure have diversified with growing participation in sports connected to “cool" lifestyle sub-cultures such as surfing, mountain biking and skateboarding. There has been a concomitant development of tourism to accommodate an ever widening range of demands for what were once relatively niche experiences; from the visceral thrills of skydiving, water-skiing and bungee-jumping, through to the more sedate pleasures of wilderness trekking, mountain climbing or wild swimming. Clearly, as Spracklen notes, in postmodern leisure culture "what matters is the plurality of choices, the freedom to choose and the identity it confers" (2013, p. 174).

The personal significance of leisure and lifestyle to individual life-projects, the diversity of recreational activities available and the growing numbers of participants mean that conflicts of interest are inevitable. Hence, life politics has increasingly moved from the personal realm to dialogue in the public sphere involving political and sub-political actors whose focus is upon what Habermas calls "the grammar of forms of life" (1987, p. 392). This is no more so than when it comes to land and water use for recreational purposes where tensions are generated: 
- Between the interests of property owners (for privacy and economic utility) and those who seek access for recreational purposes; for example, farmers versus campers or walkers.

- Between those who aim to preserve sustainable biodiversity and natural landscapes, and recreationists whose presence may impact negatively upon such goals, for example seaside landowners versus jet-skiers.

- Between individuals and groups engaged in different activities (for example kayakers versus anglers occupying the same space) or even the same recreational activities (for example surfers competing for the same waves) (Funck, 2006; Young, 2007; Olivier, 2010; MacLennan and Moore, 2011; Morgan-Davies et al., 2015).

Variations in national and regional socio-economic contexts, legal-institutional frameworks and leisure cultures are important in determining how these tensions are addressed and resolved. In relation to the right to roam, Norway, Finland and Sweden currently have legislation that is the most permissive in the world. Access rights to the countryside environment are areal and universal, with the only caveats being legal obligations to ensure that no damage occurs, that privacy be respected, and that economic activity is not disrupted. Informal codes of country recreational behaviour (e.g., in Sweden the "golden rules") are combined with education in formal environmental codes. Added to this, participatory stakeholder management bodies engage in dialogue to ensure that this system, which is popularly conceived as allemannsretten (everyman's right) works for all the parties concerned (Campion and Stephenson, 2014).

Even in Scandinavia, public access rights have not gone uncontested by private property interests (grunneierretten) where farming, tourism and development around popular fjord shorelines is concerned. However, the public interest in access has largely prevailed 
because at the heart of the Nordic conception of citizenship is a deeply embedded tradition of outdoors sporting and recreational activity, as embodied in a cultural sensibility towards friluftsliv (a simple life in nature) and idrett (purposeful outdoor sporting activity), underpinned by the notion of allemannsretten (Sandell and Fredman, 2010). Other national states have developed more limited systems of access which are partially areal (specifying particular geographic spaces) and partially lineal (centred upon designated pathways), but in both theory and practice the tendency has been to privilege landowners' rights to exclusion over public access.

In the UK, Scotland has pioneered a shift toward the Nordic model with the Land Reform (Scotland) Act 2003, which put free public access to most of the countryside and inland water on a statutory basis. This legislation will be supplemented by a Land Reform Bill that in 2016 is making its way through the legislative stages of the Scottish Parliament. In the rest of the UK, a much more restrictive and piecemeal system of access prevails, and is enforced by punitive trespass laws. Historically, private landowners and related interests have vigorously contested all attempts at reform - indeed 20 reform bills have failed in the UK parliament during the period of the $20^{\text {th }}$ century (Shoard, 1999). The last attempt at reform in this area - the Countryside and Rights of Way Act 2000, was significantly watered down after intense lobbying. Although this Act introduced a conditional right of public access to walk upon limited parts of the English and Welsh countryside, $98 \%$ of rivers remain out of bounds.

There are currently ongoing campaigns led by organisations such as the Ramblers Association, the British Canoe Union, The Land is Ours, and related water and sports organisations, for reforms that would move the rest of the UK towards the Scottish, and by extension Nordic model. Liberalization is strongly opposed by private interests through, for example, the Countryside Landowners Association, the Intrusive Footpaths Campaign, the 
National Union of Farmers, and various Anglers Associations. As Parker states, land governance has historically been "subject to continual, if only periodically visible, resistance and contestation and a vigorous, sometimes brutal defence. The issues discussed are rooted in deeply political, if modernist notions of equity, justice, liberty and equality" (2002, p. 103). In other words, the issues pertaining to the right to roam are inseparable from the realm of political philosophy, to which this chapter now turns.

\section{Allemannsretten versus the Green Leviathan}

In political philosophical terms the debate surrounding the right to roam revolves around the status of private property - the axiological institution which modern capitalist societies are organised around. Social contract theory of the $17^{\text {th }}$ and $18^{\text {th }}$ centuries as articulated with different emphases by Hobbes, Locke, Rousseau and Kant, created a pervasive foundation myth bound up with the transition from an unbounded property-less and primitive state of nature to a bounded propertied and sophisticated society. As Smith argues, the social contract "was an agreement to enter into the moral and political order of civilization, to limit one's inherent freedoms and control one's inherent (selfish) nature in the name of reason and social progress" (2011, pp. 67-68).

Modern analytical political theory and philosophy has evolved around questions of justice pertaining to the trade-offs between individual freedoms, their allocations as embodied in rights and duties, how they relate to conceptions of citizenship and the notion of what constitutes mutual benefit in the good social contract. In the context of the debate surrounding the right to roam, this dialogue has traditionally on focused upon the balance between the rights of property owners - for example to privacy, economic utility and amenity 
- and the rights of the public to access that property for recreational purposes. The type of property concerned; countryside landscapes and green spaces including rivers, lakes, shores, mountains, wilderness, farmland and forests, is clearly different from other property forms because of its public nature, and in democratic societies is therefore potentially open to challenge from those interest groups who campaign for free access on the basis of public interest (Warren, 2002). In straightforward left versus right terms the right to roam is therefore "an enduring site of class struggle... with the landless seeking to establish their 'moral' right to roam in contradistinction to the 'landed' seeking to maintain the hegemony of private property" (Ravenscroft, 1995, p. 64).

Over the past few decades, environmental sustainability and environmental justice have added extra dimensions of complexity to the right to roam debate that blurs traditional left versus right fault lines. As famously defined in the Brundtland Report, development that is sustainable "meets the needs of the present without compromising the ability of future generations to meet their own needs" (1987, p. 8). From the green perspective this intergenerational ethical duty must take precedence in all decisions concerning the allocation of rights amongst the current generation. This involves a precautionary approach that is most loudly articulated in the contemporary demands of the environmental movement to tackle global warming. The environmental justice movement's aim is firstly "to equalize the burdens of pollution, noxious development, and resource depletion" (Shrader-Frachette, 2002, p. 6). Secondly, its aim is to equalise access to environmental goods, including the right to roam. For example, Wightman has argued that "just as free speech is regarded as a fundamental right, so should access... Freedom to roam is the natural condition of humanity" (1996, pp. 198-99).

The growing influence of the environmental justice movement can be seen in the European Council on Environmental Law's conclusion in 2006 that free access to nature 
should be a universal human right. This recommendation was sustained in the 2010 United Nations Environmental Programme Draft Declaration on the Environment and Human Rights. In its deliberations the European Council concluded that access to nature is "essential for physical and psychological health of human beings and a key element of individual and social well-being". It also noted that such access is "acutely threatened by, inter alia, rapid urbanization, changing interpretations of property rights, the commodification and parcelling of nature and the landscape, increasing alienation of humans from nature and failures in land use plans" (Scannell, 2010, p. 229).

Growing environmental consciousness coupled with sociological trends towards life politics has led to an increasing demand for access to nature. As a result, the environmental justice movement has successfully moved this issue to the top of the international legal agenda, while encouraging numerous localised campaigns across the world for a right to roam that mirrors Nordic allemannsretten. Yet paradoxically, this call for environmental justice pertaining to access stands in contradiction to the demand for environmental sustainability due to the negative impacts that increasing numbers of recreational users and their activities will have. It is also the case that the more people who utilize environmental amenity and resources - scarce or otherwise - will potentially detract from the recreational experience of all those who are sharing the same environment. This paradox was (in)famously recognised by Hardin who argues that "freedom in a commons brings ruin to all" (2000 [1968], p. 189), the key claim that stands at the heart of his influential "tragedy of the commons" thesis. In relation to the right to roam issue he gives the example of:

The National Parks.... At present, they are open to all, without limit. The parks themselves are limited in extent - there is only one Yosemite Valley - whereas population seems to grow without limit. The values that visitors seek in the parks are 
steadily eroded. Plainly, we must soon cease to treat the parks as commons or they will be of no value to anyone.

(Hardin, 2000 [1968]: 189)

For Hardin it is not only human experience that is degraded when environmental resources are left open to free public access, but more seriously in terms of consequences for interconnected human life, it is environmental biodiversity that is inevitably destroyed. He uses the game theory metaphor of a pasture held in common which herders inevitably overgraze, and points to the way that other common resources such forests are logged to ruin, seas are over-fished, and air and land is polluted. Population growth is the main enemy - indeed Hardin argues in an explicitly Malthusian manner that "freedom to breed is intolerable", because ever more individuals in a finite eco-system cannot do anything else but enter into self-defeating competition for ever dwindling resources. Population density is particularly problematic due to the fact that "using the commons as a cesspool does not harm the general public under frontier conditions, because there is no public; the same behaviour in a metropolis is unbearable" (Hardin, 2000 [1968], p. 190). Welfare and human rights pertaining to family size compound this problem - no doubt Hardin would be horrified by the right to roam recently being designated another such legal human right.

Hardin's foundational assumption is a Hobbesian view of human nature whereby human beings have infinite desires and diverse appetites that they will always rationally seek to maximise at an individual level. Humans are possessed by what Hobbes calls a propensity to "felicity", which in the state of nature leads to a state of war "of every man against every man... and which is worst of all, continual fear, and danger of violent death; and the life of man, solitary, poor, nasty, brutish and short" (Hobbes, 1955 [1651], p. 82). For Hobbes, this pre-moral situation is escaped through an application of reason that enables the recognition 
that peace is of mutual benefit. Peace can only be attained by 'the covenant of every man with every man' - a social contract - whereby each says to the other "I authorize and give up my right of governing myself, to this man, or to this assembly of men, that thou give up thy right to him, and authorize all his actions in like manner". This unification signifies the birth of the Commonwealth, "the great Leviathan... that mortal god" (Hobbes, 1955 [1651], p. 112), whose first duty is to institute the law of property as the foundational basis of morality in a peaceful civil society.

Hardin's solution to the tragedy of the commons is also suitably Hobbesian - he does not trust moral imperatives or educational propaganda because free riders will always undermine self-regulation - and he categorically rejects Bentham's utilitarian argument that it should be possible "to maximise the greatest good for the greatest number" because individual goods are incommensurable. For Hardin, as for Hobbes the aim of the social contact is security, and history indicates that this goal will only be achieved by 'mutual coercion, mutually agreed upon by the majority', exercised by a strong centralized state through administrative law which protects extensions of enclosure and private property as well as limiting population. From this perspective, allemannsretten like fecundity constitutes a legally sanctioned state of nature and should be avoided at all costs.

Hardin acknowledges that liberals will baulk at his proposals because they run counter to dominant conceptions of rights and freedom. He counters liberal objections with an appeal to situational ethics whereby 'the morality of an act is a function of the state of the system at the time it is performed' (Hardin, 2000 [1968], p. 190). This type of relativism can be criticised as ethically dubious, but Hardin justifies his Green Leviathan on the ontological grounds that it would be more dangerous to not prevent the unfolding environmental tragedy. Social stability and human security must be paramount, so in Hardin's view desperate times call for desperate measures. 
Since its publication in 1968, Hardin's tragedy thesis has provoked significant debate across the social and life sciences in relation to questions of land ownership forms and sustainable development, the management of access and the calculation of environmental carrying capacity. It has also fed into green political philosophy where it is associated with conservative authoritarianism (Dobson, 1997), a position which, given the seriousness of the negative impacts of global warming, could become increasingly attractive as its effects become ever more apparent. Hardin's thesis has been widely criticised for perpetuating elitist topdown technical/managerial approaches to public access which ignore social scientific research showing viable living real-world alternatives in the form of collaborative community based dialogic approaches (Ostrom, 1990). Williams summarises the main points of critique when he argues that Hardin's thesis "ignores contextual factors such as history and culture, it underestimates the ability of people to cooperate in commons situations and it emphasizes property rights to the exclusion of other factors" (Williams, 2001, p. 365). In terms of social contract theory, the deontological liberal approach developed by Rawls offers the most significant and comprehensive alternative to Hardin's pessimistic authoritarianism.

\section{Allemannsretten and Justice as Sustainable Fairness}

Since its publication in 1971 Rawls' A Theory of Justice has become a foundational text for contemporary welfare state liberalism in much the same way that Marx's Capital (1867) is for the socialist tradition. Its precepts have been debated ad nauseam by scholars, students and political commentators, while Rawls himself modified and honed the argument presented in follow-up books and revisions of his original thesis (Rawls, 1996; 1999; 2001). It is not the intention here to revisit these discussions. Rather, we will briefly explore Rawlsian contract 
theory in order to identify possible applications and potential extensions which may provide a basis for situating the issue of free public access to the environment within a broad distributional justice framework that takes account of the ecological concerns that are raised by Hardin and environmentalists more generally.

Rawls' social contract starts from the Kantian premise that in a society containing free and equal individuals, reasonable value plurality concerning religion, morality and conceptions of the common good will be irreducible. Therefore, in order to treat individuals as ends in themselves, a just social contact must accommodate that plurality so that individuals can pursue individual life projects with self-respect and dignity. Again following Kant, for Rawls human beings possess a capacity for practical reason, and a capacity to be reasonable which are the integral ingredients of a sense of justice that is both reciprocal and fair. Hence, given the right conditions, free and equal moral agents recognize that it is necessary to agree to disagree with others over reasonable conceptions of the good and to cooperate in devising fair first principles of justice that inform "well ordered" stable political and institutional arrangements. This enables all to pursue their own reasonable conceptions of the good.

The domain governed by these arrangements as informed by the exercise of public reason - what Rawls calls the "basic structure" - is necessarily thin because the overlapping consensus will breakdown if it is extended beyond what the contracting parties can agree is fair and reasonable. These first principles are of the utmost importance to Rawls conception of justice as fairness because they form the background consensus through which key social, political and legal institutions are devised and the framework through which life-chance determining primary goods are distributed. The initial situation where first principles are chosen must therefore ensure that no one is advantaged or disadvantaged in the contracting process (Rawls, 1999, pp. 6-10). 
It is here that Rawls employs his famous heuristic device whereby an original position of equality is imagined in which the contracting parties are cast under a hypothetical "veil of ignorance". Hence "no one knows his place in society, his class position or social status, nor does anyone know his fortune in the distribution of natural assets and abilities" or even "their conceptions of the good or their special psychological propensities" (Rawls, 1999, p. 11). All that is assumed of the contracting parties is rationality, mutual disinterest and a sense of justice, and all they know is that moderate scarcity defines the economic conditions of the society and the primary goods that they are bargaining about. Rawls argues that on this original position two key principles of justice as fairness will be agreed by the contracting parties:

First: each person is to have an equal right of the most extensive scheme of equal basic liberties compatible with a similar scheme of liberties for others.

Second: social and economic inequalities are to be arranged so that they are both a) reasonably expected to be to everyone's advantage, and b) attached to positions and offices open to all.

(Rawls, 1999: 53)

These principles are used to determine the basic structure of society, rights, duties and social and economic advantages. The first principle of liberty, which is concomitant to the political sphere, has lexical priority over the second difference principle, which is concomitant to the social and economic sphere. They are applied together in the allocation of primary goods which Rawls describes as "the things that every rational man is presumed to want" regardless of life project. These include basic rights and liberties, freedom of movement, occupational choice, opportunities to hold office in the basic structural institutions, income, wealth and 
most significantly for Rawls, the social bases of self-respect. Included amongst basic rights as primary goods is the right to own personal property. However, Rawls is quite explicit that the application of the liberty and difference principles means that this right does not include "the right to own certain kinds of property (e.g., the means of production) and freedom of contract understood as laissez-faire" (Rawls, 1999, p. 54). As Abplanalp (2010), says in his commentary:

Free and equal citizens can still develop and pursue a reasonable conception of the good without the absolute right to own a phone company or a coal mine. Denying a citizen the basic property right to a river or a forest will not undercut the social basis of her self-respect. But unlike owning the means of production, personal property is undoubtedly required for a reasonable citizen to pursue their conception of the good'.

Rawls distinguishes the index of "social primary goods" from "natural goods" such as "health and vigour, intelligence and imagination" that may be influenced by the basic structure but are not directly under its control (Rawls, 1999, p. 54). According to Rawls the contracting parties will move through a four stage procedural sequence. This process gradually lifts the veil of ignorance as the deliberative process moves from first principles, through a constitutional convention to a legislature, and finally to a fully operational liberal society where public reason is being exercised in accordance to justice as fairness (Rawls, 1999, pp. 171-76).

When it comes to the issue of the right to roam, in the Rawlsian contract it could be conceived of as being resolved through trade-offs concerning basic freedoms such as freedom of movement and the right to hold personal property. A strong case can also be made that the 
contracting parties would consensually adopt a form of allemannsretten. This would enable individuals to pursue reasonable life political goals that involve public access to land and water for leisure and recreation purposes, because such goals are an essential basis for the attainment of self-respect. However, the environmental issue would remain unresolved unless the distribution of environmental goods is included in Rawls' index of primary goods. Indeed, environmental ethicists argue that social systems must be located as operating within a natural environment. Hence, natural capital should be understood as a "meta-primary" good - "that is, without it none of the other primary goods could exist" (Ashford and Hall, 2011, p. 66).

Rawls is often criticised by green political philosophers for developing an irretrievable anthropocentric perspective that excludes the natural environment and animal species from his framework of justice as fairness (Curry, 2006). Other green theorists have argued that there are resources within Rawlsian theory that can be utilised to develop a form of liberal ecologism. Most notably, this includes his notion of a just savings scheme that addresses the issue of intergenerational justice (Dobson, 1998; Postma, 2006). Under the veil of ignorance in the original position the contracting parties do not know to which generation they belong. They thus do not know "if it is poor or relatively wealthy, largely agricultural or already industrialized" (Rawls, 1999, p. 254). The reciprocity which stands at the heart of justice as fairness therefore cannot be limited to the contemporary generation and must be applied so that no generation is disadvantaged when it comes to the basic liberties and the distribution of primary goods. If the ability to live in a clean and safe environment is added to the index of primary goods alongside a public right of access, a background consensus of environmental values will inform public policy concerning sustainable practice. 
Ashford and Hall (2011), suggest that if natural capital is recognised as a primary good, and a just saving scheme is adopted, then the contracting parties would add a third principle of justice along the following lines:

Social arrangements are to be organised so that they:

a) Protect and continually improve the environment, especially for those individuals and species most heavily affected by environmental degradation and pollution.

b) Do not result in actions that exceed ecological carrying capacity.

This third principle would ensure justice as sustainable fairness. Environmentalists might argue that this principle should come first in terms of lexical priority - that it should become a meta-ethical principle of justice. However, as Ashford and Hall (2011) argue, it should stay as third in terms of lexical priority because to do otherwise would disrupt the overlapping consensus generated by the first principle that guarantees social stability, and thereby destroy the elegance of Rawls' social contract. This move would also potentially lead back to Hardin's authoritarian solution to the issues of sustainability and public access to the environment - a position that stands in direct opposition to liberal principles of justice as fairness, and the way that real working liberal democracies are constituted.

\section{Towards an Inclusive and Sustainable Leisure Citizenship}

Right to roam campaigners point to the Nordic model as an example for their own national states to follow. They counter objections made on the grounds of non-universalisable cultural 
specificity by noting that allemannsretten is the product of concrete democratic political choices about the nature of citizenship and the significance of outdoor leisure made by the Nordic states in the early part of the $20^{\text {th }}$ century. For example, in $1918-19$, the Norwegian parliament, under pressure from the labour movement in the wake of the Russian Revolution, uniquely legislated for leisure with division of the day into three equal eight hour segments for work, recreation, and rest. As Riddich argues, "the inclusion of leisure as a state sanctioned activity - perhaps even a statutory obligation - had a profound impact on public attitudes" (Riddich, 2015, p. 239), and cemented allemannsretten as a key component of recreation in the public consciousness. In Sweden, modern allemannsretten was mentioned in law for the first time in the 1960s, though its origins can be traced to the 1930s when the government decided to revive the ethic of free public areal access in order satisfy the growing demand for recreational amenity. Initially opposed by landowners, it was strongly supported by the public and had the added advantage of avoiding the expense, and legal complications of national park creation (Campion and Stephenson, 2010).

What the Nordic experience shows is that liberal states can achieve a pragmatic democratic consensus that balances the right to roam with the rights of property owners. This consensus can be viewed in Rawlsian contract terms as operating at the level of an inclusive background value consensus concerning the distribution of primary social goods. Allemannsretten and the related friluftsliv, and idrett, are inseparable from Nordic citizenship that over time has come to redefine property rights quite differently from the exclusive ownership model that remains dominant in other liberal democratic states. While private property remains the primary form of land ownership, "rights are commonly viewed as an entitlement to benefit from property and not as ownership of the land itself". Added to this conception of property is an emphasis on environmental sustainability so that 'although productive values take precedence on private rural property, there is a strong expectation that 
private land will also serve recreational and conservation purposes' (Campion and Stephenson, 2010, p. 24).

Hardin's Hobbesian Leviathan may appeal to authoritarian Greens who place sustainability above all other values, and to landowners who remain wedded to neo-liberal property rights. However, the fact that access to nature is increasingly being recognised as a human right that works in tandem with environmental justice, illustrates that the consensus on this issue is slowly shifting. The Rawlsian social contract, developed to encompass an orientation towards the natural world, offers a political justice model from which to inform processes aimed at closing the gap between the ideal and the real in relation to the issues of free public access and sustainability.

\section{Concluding Thoughts}

Individuals are increasingly seeking self-actualisation through consumer, ethical and health related lifestyle choices in the field of leisure and recreation, leading to situations where conflicts of interests concerning the right to roam are inevitable. On the one hand it can be argued like Hardin that a libertarian attitude to access results in degradation to both human experience and the natural environment, but as this chapter has shown, Rawls' deontological, liberal approach (incorporating Kantian elements) to the social contract is not necessarily incompatible with sustainability.

In short, our argument is that legislators in states where the right to roam remains contested ought to adopt a "greened" version of Rawls, arriving at political decisions underpinned by democratic consensus, ultimately leading to a modified conception of private 
property. It is of course not possible to re-create the conditions of Rawls' hypothetical original position, but as Rawls indicates in Political Liberalism (1996):

The OP serves as a means of public reflection and clarification. It helps us work out what we now think, once we are able to take a clear and uncluttered view of what justice requires when a society is conceived as a scheme of cooperation between free and equal citizens from one generation to the next.

Applied to the right to roam issue, Rawls heuristic device can be used to inform the creation of formal and informal fora which enable all stakeholders to engage in dialogue that can lead to mutual recognition of the diverse interests at play, and thereby facilitate reasoned consensus formation about rights and duties. Here it might also be suggested that Habermas' conception (1992) of the open-ended communicative dialogue with its procedures aimed at removing power differentials amongst the parties involved to construct an ideal speech situation, compliments the Rawlsian approach. Habermas, like Rawls points to the ideal-type of democratic process through which the release of public reason might operationalized in relation to the right to roam issue

In the messy, far from ideal real world, allemannsretten is the most progressive living example of how the rights and duties of co-agents can be balanced through dialogic processes involving all stakeholders to reach consensus. The experience of the Nordic states shows in practice, that only by the public being in nature, can a leisure culture be developed in which the public learns to respect nature as citizens of an environment that is intrinsically linked to their status of citizens of a democratic society. This cultivation of a sense of shared 
ownership, and therefore shared responsibility, is surely the first step towards establishing an inclusive, fair and environmentally sustainable leisure citizenship. 


\section{References}

Abplanalp, E. (2010) Background Environmental Justice: An Extension of Rawls's Political Liberalism. Philosophy Dissertations, Theses and Student Research, Paper 2.

Abramson, P. and Inglehart, R. (1995) Value Change in Global Perspective. Ann Arbor: University of Michigan Press.

Ashford, N.A. and Hall, R,P. (2011) Technology, Globalization and Sustainable Development. New Haven, London: Yale University Press.

Benson, J. ed. (2000) Environmental Ethics. London: Routledge.

Bryden, J., Brox, O., and Riddich, L. eds. (2015) Northern Neighbours - Scotland and Norway since 1800. Edinburgh: Edinburgh University Press.

Campion, R. and Stephenson. J. (2014) Recreation on Private Property: Landowner Attitudes towards Allemansratt. Journal of Policy Research in Tourism, Leisure and Events, 6 (1), pp. $52-65$.

Campion, R. and Stephenson, J. (2010) The ‘Right to Roam': Lessons for New Zealand from Sweden's Allemansratt. Australian Journal of Environmental Management, 17 (1), pp. 18-26.

Curry, P. (2006) Ecological Ethics. Cambridge: Polity Press. 
Davies-Morgan, C., Wilson, R., and Waterhouse, T. (2015) Use or Delight? History of Conflicting Hill Land Uses in Scotland - a Review. Scottish Geographical Journal, 131 (2), pp. 98-112.

Dobson, A. (1997) Green Political Thought. London: Routledge.

Dobson, A. (1998) Justice and the Environment. Oxford: Oxford University Press.

Funck, C. (2006) Conflicts over Space for Marine Leisure: A Case Study of Recreational Boating in Japan. Current Issues in Tourism, 9 (4-5), pp. 459-480.

Gammon, S. and Elkington, S. eds. (2015) Landscapes of Leisure: Space, Place and Identities. Basingstoke: Palgrave MacMillan.

Giddens, A. (1989) The Consequences of Modernity. Cambridge: Polity Press.

Giddens, A. (1991) Modernity and Self-Identity: Self and Society in the Late Modern Age. Cambridge: Polity Press.

Habermas, J. (1987) The Theory of Communicative Action, Vol 2. London: Beacon Press.

Habermas, J. (1992) The Theory of Communicative Action, Vol 1. London: Beacon Press.

Hobbes, T. (1955) Leviathan. Oxford: Basil Blackwell. 
Hardin, G. (2000) The Tragedy of the Commons. In: Benson, J. ed. Environmental Ethics, London: Routledge, pp.185-196.

Inglehart, R.F. (1990) Culture Shift in Advanced Society. Chichester. W Sussex: Princeton University Press.

Inglehart, R.F. (2008) Changing Values Among Western Publics from 1970 to 2006. West European Politics, 31 (1-2), pp. 130-146.

Maclennan, J. and Moore, R.L. (2011) Conflicts Between Leisure Subworlds: the Case of Appalachian Trail Long Distance Hikers. The Cyber Journal of Applied Leisure and Recreation Research, 13 (1), pp. 1-17.

Olivier, S. (2010) "Your Wave Bro": Virtue Ethics and Surfing. Sport in Society, 13 (7/8), pp. 1223-1233.

Ostrom, M. (1990) Governing the Commons: The Evolution of Institutions for Collective Action. Cambridge: Cambridge University Press.

Parker, G. (2002) Citizenships, Contingency and the Countryside. London: Routledge.

Postma, D.W. (2006) Why Care for Nature? In Search of a Cultural Framework for Environmental Responsibility and Education. Didrecht, Netherlands: Springer Press.

Rawls, J. (1996) Political Liberalism. New York, NY: Columbia University Press. 
Rawls, J. (1999) A Theory of Justice, Rev. ed. Oxford: Oxford University Press.

Rawls, J. (2001) Justice as Fairness: A Restatement. Cambridge, MA: Harvard University Press.

Riddich, L. (2015) Access, Nature and the Great Outdoors - Norway and Scotland. In: Bryden, J., Brox, O., and Riddich, L. eds. Northern Neighbours - Scotland and Norway since 1800 Edinburgh: Edinburgh University Press, pp. 230-249.

Rojek, C. (2001) Leisure and Life Politics. Leisure Sciences, 23 (2), pp. 115-125.

Rojek, C. (2010) The Labour of Leisure. London: Sage.

Ravenscroft, N. (1995) Recreational Access to the Countryside of England and Wales: Popular Leisure as the Legitimation of Private Property. Journal of Property Research, 12 (1), pp. 63-74.

Sandell, K. and Fredman, P. (2010) The Right of Public Access - Opportunity or Obstacle for Nature Tourism in Sweden?. Scandinavian Journal of Hospitality and Tourism, 10 (3), pp. 291-309.

Scannell, Y. (2010) A Right of Access to Nature. Environmental Policy and Law, 40 (5), p. 229. 
Shoard, M. (2000) A Right to Roam: Should we Increase Access to Britain's Countryside. Oxford: Oxford Paperbacks.

Schrader-Frachette, K. (2002) Environmental Justice: Creating Equality, Reclaiming Democracy. Oxford: Oxford University Press.

Smith, M. (2011) Against Ecological Sovereignty. Minneapolis, London: University of Minnesota Press.

Spracklen, K. (2013) Leisure, Sports and Society. Basingstoke: Palgrave MacMillan.

Warren, C. (2002) Managing Scotland's Environment. Edinburgh: University of Edinburgh Press.

Wightman, A. (1996) Who Owns Scotland. Edinburgh: Canongate.

Williams, D.R. (2001) Sustainability and Public Access to Nature: Contesting the Right to Roam. Journal of Sustainable Tourism, 9 (5), pp. 361-371.

Wilson, E.O. (2000) The Environmental Ethic. In: Benson, J. ed. Environmental Ethics. London: Routledge, pp. 153-160.

Young, H.C. (2007) Understanding Water Rights and Conflicts. E. Florida: Burg Young Publishing. 
